\title{
FASILITAS KREATIVITAS SENI MERUYA UTARA
}

\author{
Anthea $^{1)}$, Rudy Surya ${ }^{2)}$ \\ 1)Program Studi S1 Arsitektur, Fakultas Teknik, Universitas Tarumanagara, katarinaa_anthea@yahoo.com \\ 2) Program Studi S1 Arsitektur, Fakultas Teknik, Universitas Tarumanagara, rs88seb@gmail.com
}

\begin{abstract}
Abstrak
Fasilitas Kreativitas Seni merupakan proyek third place yang mewadahi beragam kegiatan berhubungan dengan kreativitas seni khususnya dalam bidang seni rupa. Proyek ini, dilatarbelakangi oleh tidak tertampungnya warga yang gemar melakukan berbagai kegiatan yang berhubungan dengan seni rupa terutama di kalangan remaja dan ibu rumah tangga sehingga sering menuangkan kreativitas di tempat yang tidak seharusnya. Proyek ini berlokasi di kelurahan Meruya Utara. Tujuan proyek adalah untuk memfasilitasi warga Meruya Utara sebagai third place dengan berbagai macam fasilitas yang berhubungan dengan seni agar kreativitas yang mereka miliki berkembang dan menjadikan tempat bagi warga untuk berkumpul serta bebas dalam berekspresi dan berkreasi sehingga dapat meningkatkan pribadi menjadi lebih baik. Guna menciptakan rasa kebersamaan serta mengurangi kesenjangan sosial dan tingkat keamanan yang kondusif sehingga memungkinkan berkurangnya potensi kenakalan remaja di kawasan. Metode deskriptif eksplanatoris digunakan dalam penulisan ini dengan melakukan rangkaian studi literatur, survei dan observasi lapangan dan melakukan analisis. Beberapa program yang dihasilkan diantaranya adalah art studio, galeri, display area, perpustakaan, kafetaria, taman dan distro.
\end{abstract}

\section{Kata kunci: kreatif, seni, Third Place}

\begin{abstract}
The Creative Art Facility is a third place project that accommodate various activities which is related to art creativity specially fine arst. The background of the project is residents are not provided a place to do some activities that related to arts especially among teenagers and housewives so that they often do their creativity in a wrong place. This project is located in North Meruya. This project as third place aims to facilitate Meruya Utara residents with lots of facilities that related to arts so that they can develop their creativity and become a place for residents to gather around also free to express theirselves and be creative so that they can improve personality become better. In order to create a sense of togetherness also reduce social disparity and a conducive level of security that can reduce the potential of juvenile delinquency in the region. Descriptive explanatory method is used in this writing by doing the literature studies, surveys and field observations, and conducting analyzes. Several programs that being generated are art studio, gallery, display area, library, cafetaria, garden, and artshop.
\end{abstract}

\section{Keywords: art, creative, third place}

\section{PENDAHULUAN}

\section{Latar Belakang}

Meruya Utara memiliki tingkat kesenjangan sosial yang paling tinggi dimana banyak anak remaja yang putus bersekolah, serta tingkat kemanan di kelurahan ini tergolong rendah. Hal ini dapat mengakibatkan remaja melakukan tindakan kriminal, seperti pencurian, pencoretan dinding, mengkonsumsi obat-obatan terlarang, dan sebagainya. Selain itu, minat warga kelurahan Meruya Utara yang berhubungan dengan kesenian cukup tinggi. Hal ini dapat dilihat dari banyaknya kegiatan yang berhubungan dengan seni yang biasanya diselenggarakan di 
RPTRA karena tidak ada tempat lainnya, seperti kegiatan membuat kerajinan tangan, melukis, dan membuat mural. Kelurahan Meruya Utara merupakan kawasan yang terletak di Kecamatan Kembangan yang didominasi oleh zona perkantoran, perdagangan barang dan jasa, pendidikan, dan hunian. Kawasan ini mudah diakses karena banyak pemberhentian bus di titiktitik tertentu. Tidak hanya itu, di bawah jembatan tol Meruya Utara juga dihiasi oleh mural bertemakan adat Betawi dimana para pengunjung dapat berswafoto disana. Kawasan Meruya Utara minim akan fasilitas hiburan sekaligus mengedukasi yang bersifat publik, termasuk fasilitas yang dapat memenuhi kreativitas terutama dalam bidang seni sehingga kurangnya sosialisasi antar sesama warga yang dapat menurunkan kreativitas mereka. Kawasan Meruya Utara membutuhkan suatu wadah kreativitas dan aktifitas bagi setiap kalangan yang lebih inovatif untuk melengkapi fasilitas sosial dan rekreasi kota. Wadah aktivitas dan kreativitas ini diharapkan dapat menghasilkan pribadi yang lebih mandiri dan berguna bagi generasi yang akan datang sekaligus menjadikan kawasan ini maju.

\section{Rumusan Permasalahan}

a. Program seperti apa yang mampu meningkatkan kualitas kreativitas warga dalam mengisi waktu luangnya secara positif?

b. Wadah kreatif seperti apa yang cocok untuk warga Meruya Utara sehingga dapat berekspresi dan bersosialisasi secara positif?

\section{Tujuan}

Tujuan dari proyek Fasilitas Kreativitas Seni Meruya Utara adalah:

a. Menjadikan proyek sebagai tempat bagi warga untuk berkreasi dengan aneka seni, mulai dari seni lukis hingga bisnis kreatif di tempat yang seharusnya.

b. Menjadikan proyek sebagai tempat berwisata kuliner dan tempat untuk berkumpul dengan teman-teman maupun mencari souvenir.

c. Menjadikan proyek sebagai daya tarik bagi para pengunjung untuk mengabadikan momen dengan latar belakang seni mural yang ada maupun seni lainnya.

\section{KAJIAN LITERATUR}

\section{Third Place}

Menurut Oldenburg (1999), third place merupakan tempat untuk orang yang ingin mengobati stres, kesepian, dan keterasingan. Third place adalah suatu tempat yang bisa dijadikan tempat berlindung sementara dari kebosanan dan memiliki fungsi utama yaitu menyatukan komunitas di lingkungan. Selain itu, tidak hanya dijadikan tempat untuk melarikan diri, tetapi seseorang juga dapat bersantai dan merasa terhibur serta mendapatkan ketenangan. Terdapat 7 karakteristik third place, yaitu netral bagi siapa saja dan mudah untuk diakses, tidak terikat dengan status sosial, percakapan adalah aktivitas utama, terbuka untuk siapa saja dan dapat memenuhi kebutuhan masyarakatnya, memiliki wadah dimana pengunjung mempunyai kebutuhan untuk datang ke tempat ketiga, adanya suasana yang menyenangkan sehingga memberikan rasa nyaman bagi para pengunjung, dan adanya kebebasan bagi para pengunjung untuk menunjukkan jati dirinya.

\section{Kreativitas}

Menurut KBBI, kreatif memiliki arti daya cipta atau memiliki kemampuan untuk menciptakan. Dalam kehidupan, kreativitas sangat penting karena kreativitas merupakan suatu kemampuan yang sangat berarti dalam proses kehidupan manusia. Menurut Treffinger (1980), ada beberapa nilai penting kreativitas dalam kehidupan, seperti adanya kemampuan untuk melahirkan sesuatu yang baru yang berupa pikiran maupun karya nyata dalam mengerjakan persoalan hidup bagi orang kreatif, adanya tingkat kualitas dari kinerja, karya, gagasan, dan perbuatan manusia dapat diantisipasi dari sejauh mana seseorang memiliki tingkat kreativitas 
tertentu, suatu karya kreatif sebagai hasil kreativitas seseorang dapat menimbulkan kepuasan pribadi yang tak terhingga nilainya, adanya kreativitas tinggi yang dimiliki seseorang maka seseorang tersebut akan mempunyai pengembangan diri secara optimal, dan adanya peningkatan Sumber Daya Manusia dalam era globalisasi dan era reformasi menunjukkan betapa pentingnya segi kreativitas diprioritaskan untuk dikelola dan dikembangkan secara optimal. Secara komprehensif, kreativitas dapat diartikan sebagai kemampuan dalam berpikir dan bertindak tentang sesuatu dengan cara baru dan tidak biasa guna memecahkan berbagai persoalan. Kreativitas merupakan naluri yang sudah dimiliki manusia sejak lahir, akan tetapi kreativitas tidak dapat berkembang dengan sendirinya.

\section{Seni}

Menurut $\mathrm{KBBI}$, seni berarti keahlian dalam membuat karya yang bermutu (dilihat dari segi kehalusannya, keindahannya, dan sebagainya) atau karya yang diciptakan dengan keahlian yang luar biasa seperti tari, lukisan, dan ukiran. Seni merupakan karya manusia yang melibatkan ide, gagasan, gerakan hati, perasaan, pikiran, memproses, membuat sehingga menghasilkan wujud visual yang memiliki nilai keindahan dan menimbulkan perasaan (Arifin, 2010). Seni dapat dinikmati melalui pendengaran, penglihatan, dan kombinasi keduanya. Secara umum, seni dibedakan menjadi 5 kelompok, yaitu: seni musik, seni rupa, seni tari, seni sastra, seni teater.

\section{Seni Rupa}

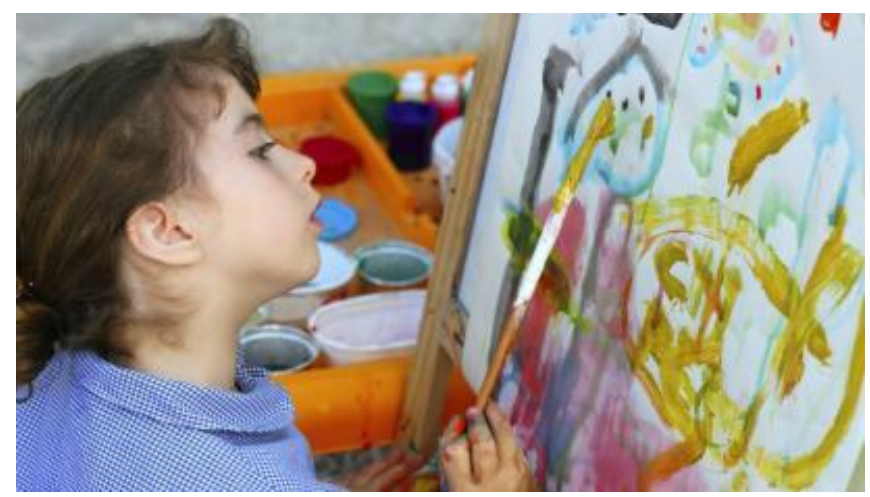

Gambar 1. Kreativitas Seni Rupa Bidang Lukis

Sumber: educenter.id

Menurut Agung (2008), seni rupa dan jenis seni lainnya adalah sesuatu yang dibuat oleh manusia dan mengandung ekspresi serta keindahan. Namun, seni rupa utamanya dinikmati oleh indra penglihatan. Hal yang dinikmati tersebut dapat berupa kualitas unsur-unsur rupa yang disusun dan memiliki kualitas harmoni, kesatuan dan ekspresi. Jadi, seni rupa adalah seni yang nampak oleh indra penglihatan dimana wujudnya terdiri dari unsur-unsur rupa seperti garis, bidang, wujud, maupun warna. Seni rupa terdiri dari:

a. Seni Lukis, merupakan bidang seni rupa murni yang memiliki bentuk 2 dimensi. Karya seni lukis biasanya dibuat di kanvas dengan menggunakan cat minyak atau cat akrilik. Seni lukis kini tidak hanya dibatasi dengan menggambar diatas kanvas, melainkan juga menggambar diatas media dinding, tembok atau permukaan luas yang bersifat permanen lainnya dengan menggunakan cat tembok, cat kayu, kapur tulis, dan lainnya yang kini disebut dengan mural.

b. Seni Kriya, biasa disebut juga dengan applied art yaitu suatu karya seni rupa yang memiliki nilai kegunaan dan seni. Karya seni rupa bertujuan untuk memenuhi kebutuhan praktis dan kebutuhan sehari-hari, misalnya furniture, tekstil, maupun keramik.

c. Seni Pahat, merupakan karya seni yang hasil karyanya berupa tiga dimensi dan biasanya menggunakan bahan dari kayu yang sudah tidak terpakai. 
d. Seni Patung, merupakan karya seni rupa yang dibentuk dengan menggunakan suatu bahan bervolume seperti tanah liat, lilin, semen, kayu, batu, maupun logam.

\section{Ruang Kreatif}

Dalam menyikapi fenomena kota yang semakin sesak karena kepadatan penduduk yang tinggi, munculah suatu gagasan pengembangan kota yang kreatif dengan menyediakan ruang publik sebagai wadah kreativitas warga kota. Ruang publik merupakan tempat warga dari berbagai kalangan berkumpul, bermain, bereskpresi, dan berinteraksi. Disaat perkotaan identik dengan kekakuan, individualis dan materialistis, ruang publik menawarkan nilai-nilai manusiawi, dinamis dan estetis yang menjadi kebutuhan dasar manusia (Buana, 2015). Keterkaitan antara ruang publik dengan kreativitas warga kota inilah kemudian sering disebut dengan istilah ruang kreatif publik (creative space), yaitu sebuah ruang yang bisa diakses oleh seluruh warga yang mampu menstimulasi kreativitas maupun sebagai wadah untuk melakukan kegiatan kreatif (Evans, 2006). Ruang kreatif publik diharapkan menjadi wadah untuk memicu aktivitas warga agar tercipta lingkungan yang kreatif (creative milieu). Menurut Lilian (2017), creative space adalah ruang fisik dimana orang berkumpul, bekerja, saling menginspirasi, belajar hal-hal baru, dan saling terhubung. Berpartisipasi dalam sebuah ruang yang membawa kita ke dalam hubungan dengan orang-orang yang memiliki pemikiran yang sama. Menurut Evans (2006) dan Borrup (2010), ada beberapa aspek mendasar yang perlu diperhatikan untuk mewujudkan ruang kreatif, yaitu:

a. Kenyamanan: ruang harus memiliki tingkat kenyamanan yang tinggi dimana ruang tidak kumuh, tidak bising dan tertata dengan baik.

b. Keterbukaan: ruang dapat menghadirkan suasana terbuka, bebas, dan tidak monoton.

c. Aksesibilitas: memiliki lokasi strategis, misalnya dekat dengan kawasan hunian, pasar maupun perkantoran sehingga mudah diakses oleh warga.

d. Toleransi: ruang kreatif harus terbuka bagi siapa saja dan tidak ada diskriminasi antar warga.

e. Keragaman: ruang kreatif harus dinamis, memberi tempat untuk berkumpul agar warga dapat bertukar pikiran.

\section{METODE}

\section{Metode Penyusunan}

Metode yang digunakan penulis dalam menyusun adalah metode deskriptif, eksplanatoris, dengan melibatkan proses komparasi kasus melalui analisis data dan sintesis.

Metode Pengumpulan DataDigunakan dengan melibatkan data primer dan data sekunder. Pengumpulan data dilakukan dengan cara observasi, pengamatan lapangan terhadap kondisi fisik dan sosial masyarakatnya, sekaligus membuat catatan terhadap objek yang dijadikan sasaran. Penulis juga melakukan wawancara dengan menggunakan metode kuantitatif kepada masyarakat kelurahan Meruya Utara untuk mengetahui pendapat serta kebutuhan penduduk. Tidak hanya itu, penulis juga menggunakan kajian teoritis dimana penulis mengumpulkan berbagai macam teori yang berkaitan dengan proyek dan permasalahan yang ada pada kawasan.

\section{Metode Desain}

Metode desain yang digunakan penulis dalam penelitian ini adalah metode transprogramming dari Bernard Tchumi (1996) yaitu terdapat dua program yang sifat dan konfigurasi spasialnya berbeda. Dalam hal ini, penulis mengkombinasikan area kerja dengan area pameran. Hal ini bertujuan agar hasil karya yang dibuat pengunjung tidak hanya dijadikan sebagai kebanggaan tersendiri tetapi juga dapat dijadikan bisnis kreatif. Area pameran tersebut dapat berupa galeri, display area, maupun distro. 


\section{DISKUSI DAN HASIL}

\section{Tinjauan Lokasi dan Tapak}

Lokasi menjadi pertimbangan awal dalam perencanaan proyek. Dalam menentukan tapak diperlukan kriteria-kriteria yang menjadi acuan agar program yang diusulkan dapat mencapai hasil dan manfaat yang sebesar-besarnya bagi masyarakat. Adapun kriteria tersebut diantaranya adalah tapak terletak di kota Jakarta karena Jakarta merupakan kota terbesar yang ada di Indonesia dan menjadi pusat kegiatan politik, ekonomi, sosial, dan budaya, tapak terletak pada lokasi yang strategis sehingga mudah dicapai baik dengan kendaraan umum maupun pribadi dan dikenal oleh masyarakat sekitar, tapak dapat menjadi permeabilitas bagi perumahan (first place) dan tempat kerja (second place), lokasi memiliki prospek lingkungan yang baik, dan tapak haruslah sesuai dengan perencanaan ruang tata kota yang ada.

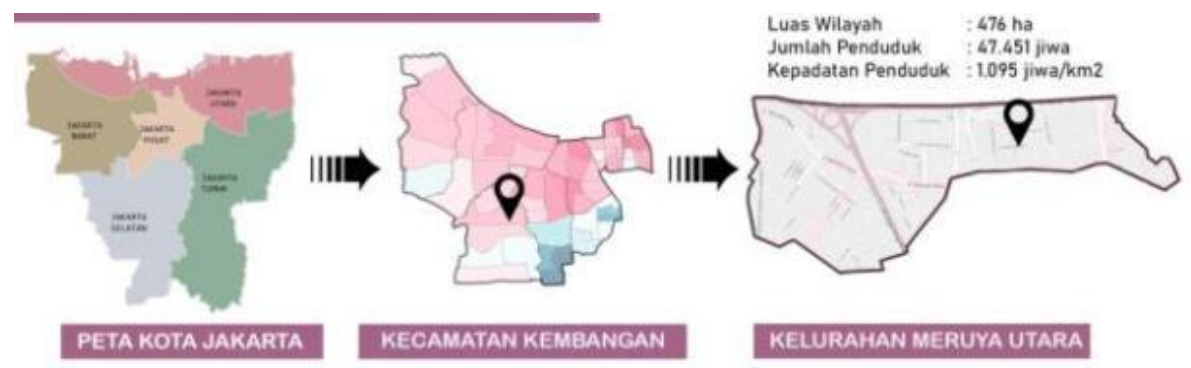

Gambar 2. Peta Kota Jakarta, Kecamatan Kembangan, dan Kelurahan Meruya Utara Sumber: Penulis, 2020

Proyek ini akan ditempatkan di kelurahan Meruya Utara dengan pertimbangan kawasan ini memenuhi beberapa kriteria menurut Oldenburg (1999) yaitu Meruya Utara merupakan Kawasan mandiri yang memiliki fasilitas lengkap dengan peruntukan fasilitas umum dan campuran serta sebagian besar merupakan kawasan hunian, kelurahan Meruya Utara belum memiliki suatu wadah yang memadai untuk menampung kegiatan yang berkaitan dengan kreativitas secara terbuka untuk berbagai kalangan.

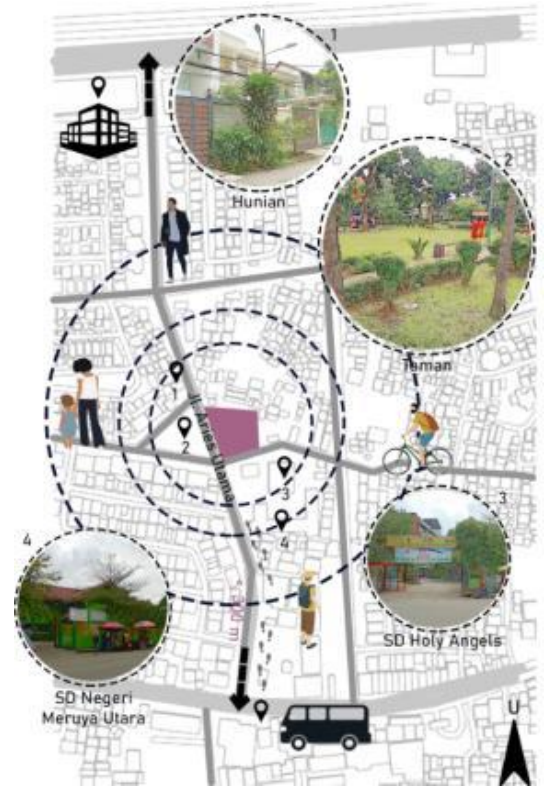

Gambar 3. Tapak dan Lingkungan Sekitar Sumber: Penulis, 2020

Tapak yang dipilih berada di Jl. Aries Utama. Tapak ini dipilih karena tapak dapat menjadi permeabilitas antara first place dan second place. First place dari kawasan ini adalah hunian dan second place dari kawasan ini adalah sekolah SD Holy Angels, SD Negeri Meruya Utara, dan 
perkantoran. Apabila menggunakan kendaraan umum seperti TransJakarta, halte terdekatnya adalah halte Kebon Jeruk. Selain itu, lokasi ini juga dilalui oleh angkutan kota bewarna merah. Pemberhentian bus terletak sekitar $300 \mathrm{~m}$ dari lokasi tapak dan dapat ditempuh sekitar 5-8 menit dengan berjalan kaki sehingga tapak mudah diakses bagi warga (accessible). Selain itu, regulasi kawasan tapak adalah zona ungu dimana sesuai dengan fungsi dari proyek ini.

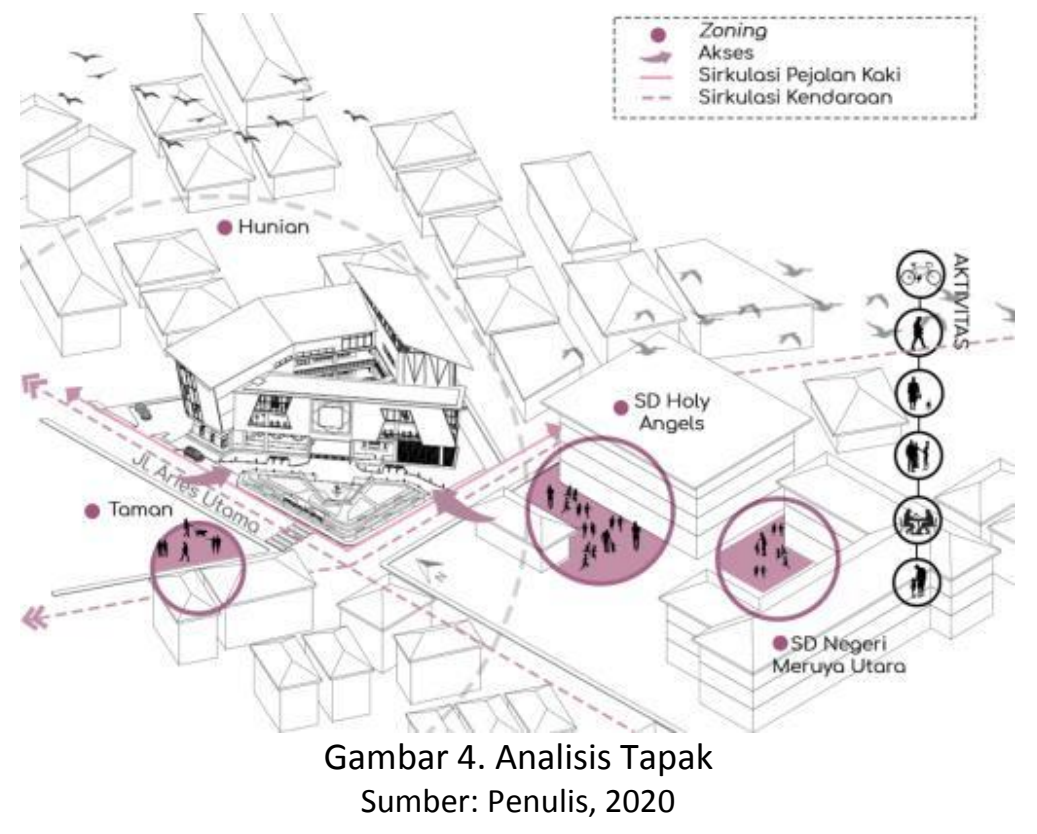

Tapak dapat diakses dari 2 arah, arah barat dan arah selatan yaitu dari Jl. Aries Utama. Kedua jalan ini merupakan jalan sekunder. Jl. Aries Utama yang terletak di sebelah barat merupakan jalan yang lebih ramai dan dominan dimana jalan ini digunakan warga untuk menuju jalan kolektor sehingga akses pada jalan tersebut tidak hanya untuk pejalan kaki tetapi juga kendaraan sebagai tempat untuk menurunkan atau menjemput penumpang. Di depan tapak terdapat taman yang berfungsi sebagai peredam kebisingan dan polusi dari jalanan. Selain itu, taman juga dapat menghasilkan view yang baik pada bangunan dan dijadikan tempat bermain bagi anak.

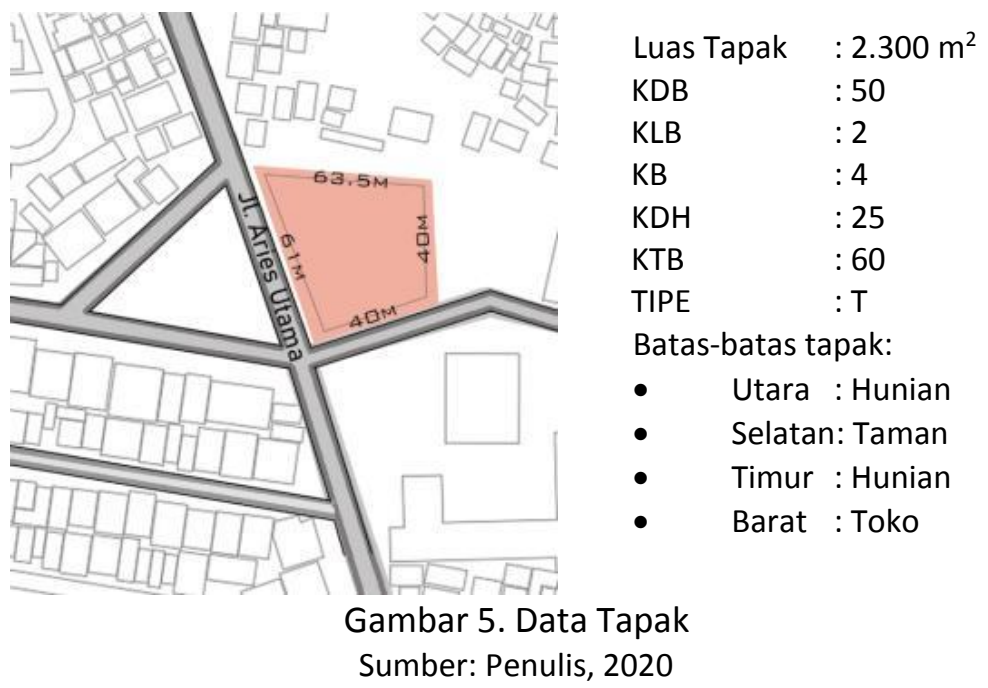

\section{Analisis Program}

Program yang diusulkan adalah fasilitas kreativitas seni Meruya Utara. Program ini diusulkan berdasarkan latar belakang yang ada pada kawasan dan mengedepankan konsep third place. 
Menurut Badan Pusat Statistik (2019), penyandang masalah kesejahteraan sosial di Meruya Utara paling tinggi dibandingkan dengan kelurahan lainnya yang ada di Kecamatan Kembangan dimana banyak anak yang tidak bersekolah atau putus sekolah. Tingkat keamanan di kawasan ini juga tergolong rendah dimana dilihat dari jumlah pos hansip hanya memiliki 44 pos hansip dan 139 anggota hansip (Badan Pusat Statistik, 2019). Jumlah tersebut termasuk sedikit apabila dibandingkan dengan kelurahan di Kecamatan Kembangan lainnya yang ratarata memiliki lebih dari 50 pos hansip dan lebih dari 140 anggota hansip. Selain itu, kreativitas dalam bidang seni rupanya cukup banyak diminati oleh warga kelurahan Meruya Utara, hal ini dapat dilihat dari banyaknya seni mural yang ada di dinding-dinding bangunan maupun di kolong jembatan kelurahan Meruya Utara dan adanya kegiatan yang cukup rutin bagi warga kelurahan Meruya Utara dalam membuat kerajinan tangan di salah satu RPTRA Meruya Utara, tetapi belum ada wadah untuk menampung aktivitas tersebut. Dengan demikian, kreativitas yang dipilih yaitu kreativitas di bidang seni rupa. Seni rupa dapat dibagi menjadi beberapa bidang sehingga untuk mengetahui bidang minat seni rupa yang paling digemari oleh warga, maka penulis menyebarkan angket kepada warga Meruya Utara.

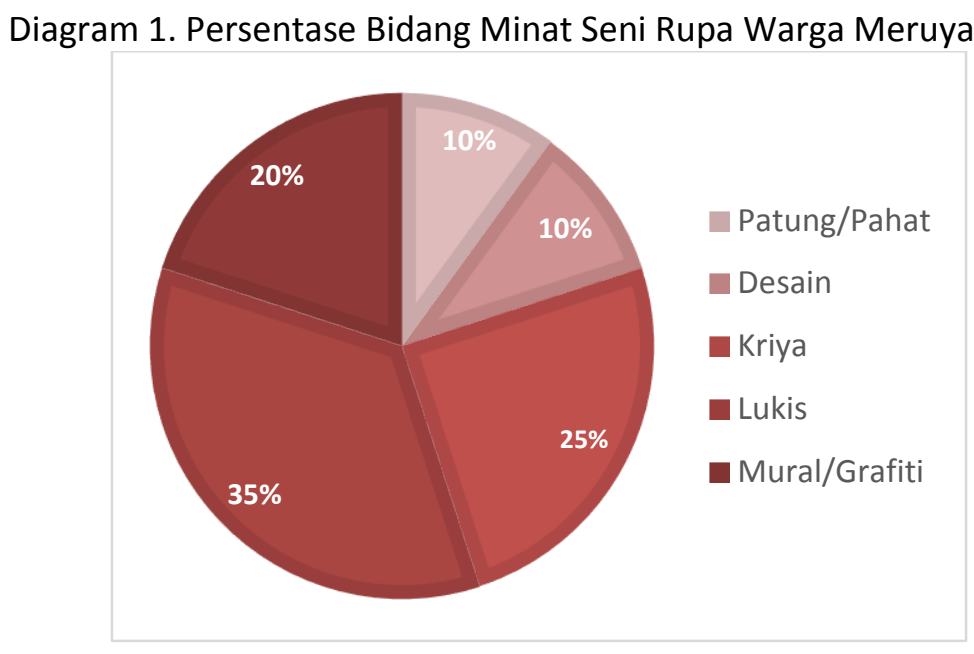

Sumber: Penulis, 2020

Dari data yang diperoleh melalui angket dapat dilihat bahwa warga yang memiliki minat seni rupa dibidang patung/pahat dan desain masing-masing sebesar $10 \%$, dibidang mural/grafiti sebesar $20 \%$, dibidang kriya sebesar $25 \%$ dan dibidang lukis sebesar $35 \%$. Dengan demikian, minat seni rupa dibidang lukis paling digemari oleh warga Meruya Utara sehingga seni lukis menjadi kegiatan seni rupa utama dimana kebutuhan ruang, jadwal kegiatan dan kapasitas pengunjung yang dapat ditampung tentunya lebih banyak dibandingkan dengan bidang seni rupa lainnya. Sedangkan, untuk kegiatan tambahan terdapat seni patung/pahat, desain, seni kriya/mozaik dan seni mural/grafiti. Untuk menampung kegiatan-kegiatan tersebut diperlukan ruang kerja atau studio.

Dengan demikian, program utama dari proyek adalah art studio. Proyek ini juga didukung oleh program pendukung lainnya yang dapat menunjang kebutuhan warga sekaligus meningkatkan kriteria third place pada proyek. Proyek pendukung tersebut diantaranya adalah galeri, kafetaria, perpustakaan, dan taman.

Art Studio

Merupakan ruang kerja untuk menampung kegiatan seni rupa dibidang patung/pahat, kriya, desain, lukis, dan mural/grafiti. Area ini dibagi menjadi 2 bagian yaitu, seni rupa indoor dan seni rupa outdoor. Program ini menarik dan dapat dilakukan oleh siapa saja, baik anak-anak maupun orang dewasa. Selain itu, program bersifat reguler karena dapat dijadikan kegiatan rutin bagi warga sekitar yang merupakan salah satu kriteria dari third place. 
- Studio Seni Rupa Outdoor

Disediakan untuk kegiatan seni rupa dibidang mural/grafiti dimana program ini paling banyak digemari setelah program lukis. Kegiatan terletak di area yang terbuka karena kegiatan ini dilakukan dengan teknik spray dan membutuhkan dinding yang cukup luas.

- Studio Seni Rupa Indoor

Disediakan untuk kegiatan seni rupa lukis, kriya/mozaik, dan patung/pahat. Studio yang berada di dalam ruangan tentunya dilengkapi dengan area cuci dan gudang penyimpanan. Studio seni lukis memiliki ukuran yang lebih luas dibandingkan dengan kriya/mozaik dan patung/pahat karena memiliki jumlah peminat yang lebih besar.

Galeri

Program ini bertujuan untuk memamerkan karya-karya yang berhubungan dengan kreativitas kesenian maupun karya terbaik yang telah dibuat oleh para pengunjung. Apabila tidak ada event tertentu, ruang tersebut dapat dijadikan sebagai tempat berkumpul dimana memenuhi kriteria third place yang ada yaitu conversation dan low profile.

\section{Kafetaria}

Program ini dapat dijadikan tempat bagi para pengunjung untuk berbincang, berkumpul, makan, dan minum dimana tujuan utamanya adalah memberikan ketenangan bagi para pengunjung yang datang. Program ini merupakan program pendukung yang penting karena merupakan salah satu karakteristik dari third place yaitu conversation.

\section{Distro/Artshop}

Program ini diadakan untuk memajang atau memamerkan karya-karya berbagai macam kreativitas terbaik yang dibuat oleh para pengunjung. Tidak hanya itu, program ini memiliki nilai ekonomi karena dapat dijadikan sebagai bisnis kreatif dimana para pengunjung dapat memperjualbelikan karyanya tersebut layaknya souvenir.

\section{Perpustakaan}

Program ini diadakan bagi para pengunjung untuk mengembangkan ide-idenya melalui bukubuku yang disediakan di perpustakaan. Program pendukung ini memiliki kriteria dari third place yaitu bersifat publik dan netral sehingga dapat diakses oleh siapa saja.

\section{Taman}

Menyediakan tempat bagi para pengunjung yang hanya ingin bersantai, duduk, berkumpul, dan sebagainya. Program ini tentunya dapat meningkatkan kriteria third place pada proyek yaitu playful, conversation, dan level. 


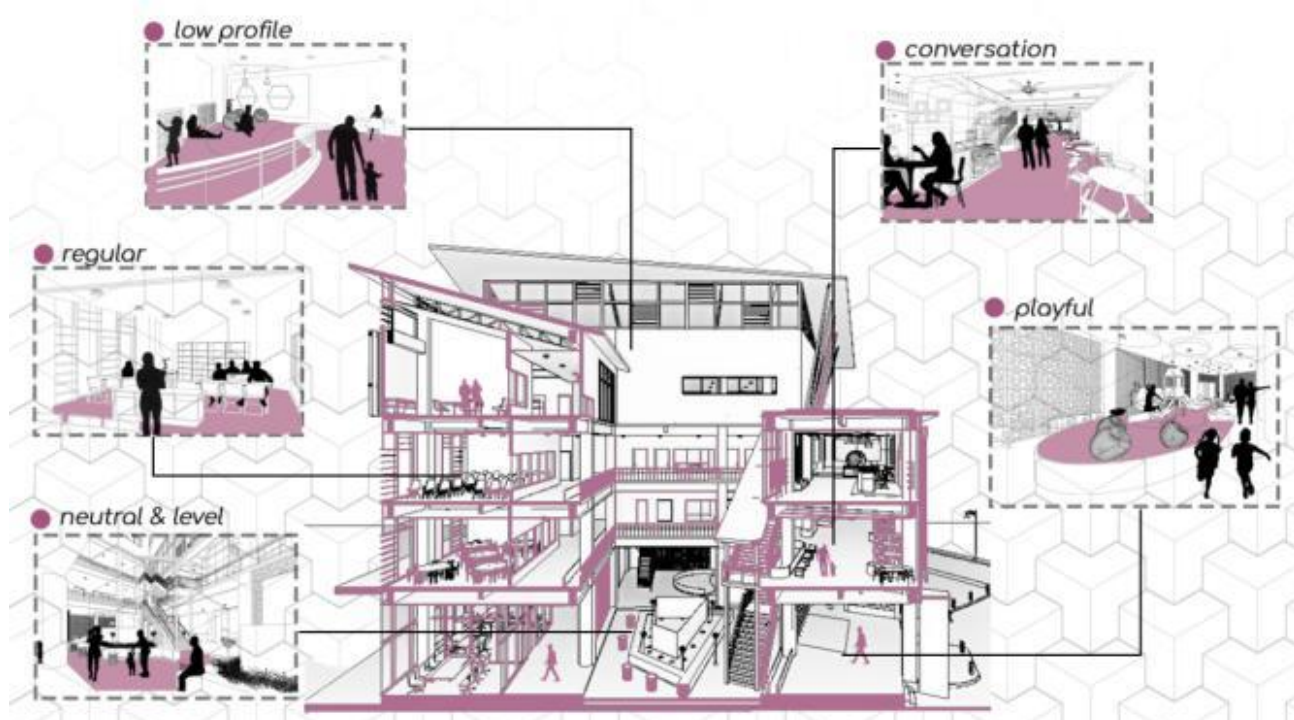

Gambar 6. Diagram Aktivitas Fasilitas Kreativitas Seni Meruya Utara Sumber: Penulis, 2020

Dengan demikian, program-program yang ada memenuhi beberapa kriteria third place menurut Ray Oldenburg karena program-program diatas dapat dinikmati oleh berbagai kalangan antara lain dalam melakukan sebuah seni tidak dibatasi oleh umur maupun gender, dapat menjadi tempat reguler bagi warga Meruya Utara karena memiliki fasilitas-fasilitas menarik yang dapat meningkatkan kreativitas, program bersifat playful karena tidak hanya orang dewasa tetapi anak-anak juga dapat menikmati dan mengikuti program yang ada, aktivitas utama dalam program ini tidak hanya melakukan kegiatan seni akan tetapi juga berkumpul dan berdiskusi, dan program ini aksesibel karena terdapat di kawasan Meruya Utara yang didominasi oleh zonasi perumahan dan perkantoran serta perdagangan barang dan jasa.

\section{Program Ruang}

Berikut adalah tabel program ruang dimana program pada bangunan dibagi menjadi 4 bagian, yaitu area kerja seni rupa, galeri, fasilitas pendukung, dan area servis.

Tabel 2. Program Ruang

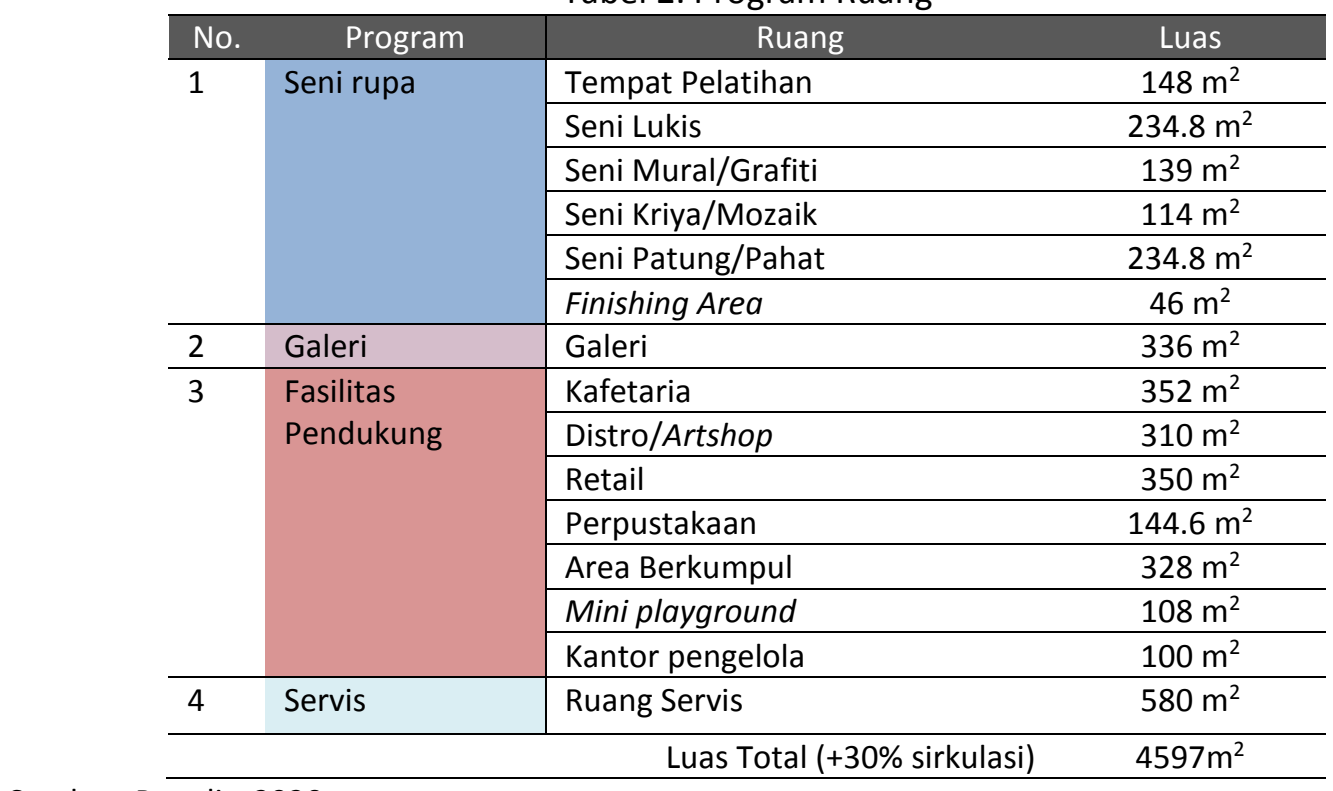

Sumber: Penulis, 2020 


\section{Bentuk Rancangan}

Proses pembentukan gubahan massa dipengaruhi oleh bentuk tapak, lingkungan sekitar, dan pendekatan transprogramming seperti yang dapat dilihat dibawah ini:

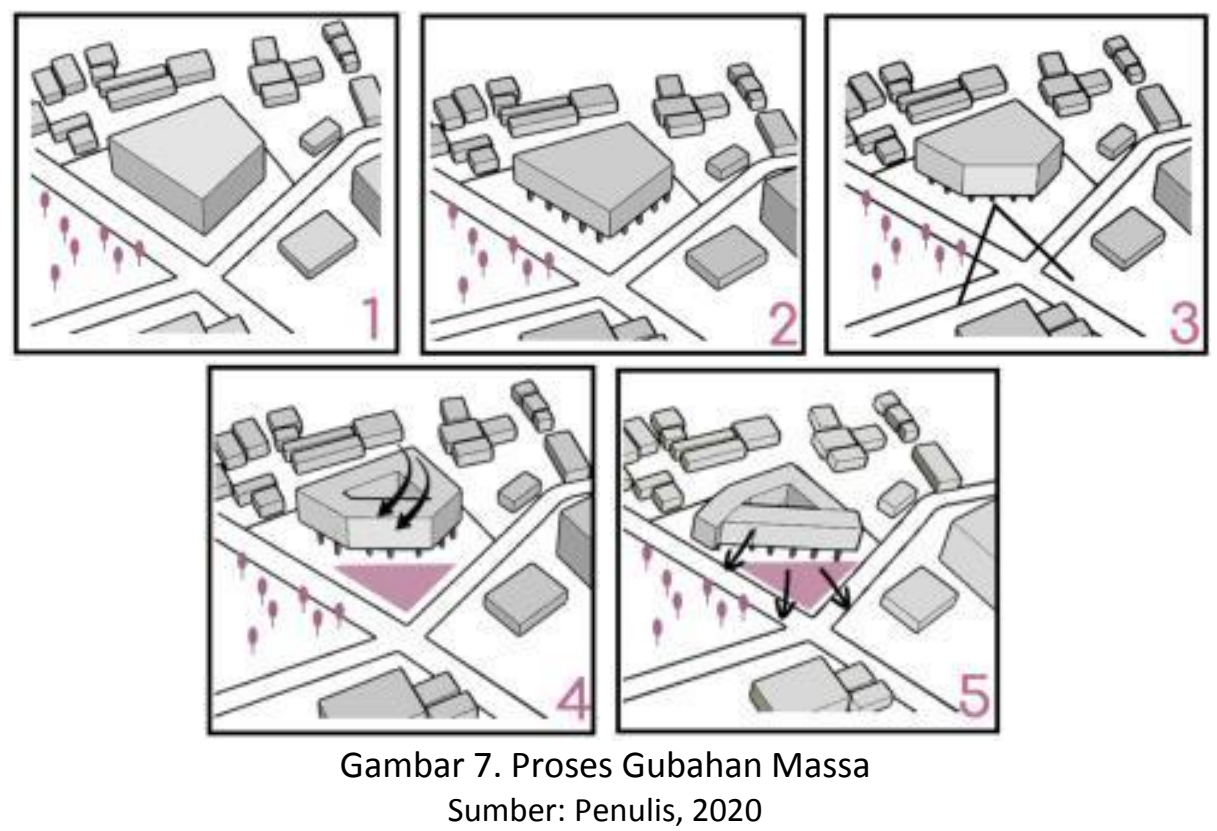

Pada tahap 1, bentuk awal massa menyerupai sebuah trapesium untuk menghargai bentuk tapak yang ada. Pada tahap 2, massa diangkat dan dipotong pada bagian sudut agar menghasilkan sudut pandang yang menarik dari arah Barat yaitu Jl. Aries Utama yang lebih mendominasi dibandingkan dengan jalan lainnya dan menjadi sirkulasi datangnya pengujung. Pada tahap 3, pada bagian sudut tapak diberi taman mural outdoor sehingga bangunan terlihat menarik dan konteks dengan taman yang ada di seberang tapak. Pada tahap 4, mengarah pada pendekatan transprogramming dimana bagian tengah bangunan diberi void yang besar yang difungsikan sebagai area pameran yang terbuka dimana program ini dikelilingi oleh area kerja dan program lainnya yang berada di dalam bangunan. Hal ini secara tidak langsung mengkombinasikan dua program yang konfigurasinya berbeda yaitu area pameran dan area kerja. Selain itu, void yang ada juga berfungsi agar bangunan tidak padat dan adanya pengudaraan serta pencahayaan yang cukup. Pada tahap 5, merupakan hasil akhir dari gubahan massa dimana material yang digunakan sebagian besar adalah bata dan terdapat juga second skin maupun partisi garis-garis yang bermaterialkan conwood. Terdapat juga roof garden pada atap sehingga menyatukan bangunan dengan taman yang ada didepan tapak.

\section{Hasil Rancangan}

Zoning pada bangunan disusun berdasarkan kebutuhan yang paling sering digunakan dan jenis ruang. Sedangkan, sirkulasi pada bangunan menujukkan pergerakan pejalan kaki pada bangunan yang diutamakan karena bangunan mengedepankan karakteristik third place yang ada dimana sebagian besar pengguna adalah warga kawasan Meruya Utara. Lantai 1 sebagian besar adalah area publik dan playful dimana terdapat lounge, mini playground, retail area, taman, display area, dan kantor. Pada bagian tengah terdapat taman dan area display outdoor. Di sekeliling taman terdapat partisi yang tidak hanya digunakan sebagai pembatas tetapi juga dapat digunakan sebagai tempat untuk memajang hasil karya seni lukis terbaik yang dibuat oleh para pengunjung. Tidak hanya itu, pada taman terdapat area duduk dimana para pengujung dapat bersantai sambil menikmati hasil karya yang ada. Lantai 1 merupakan area terbuka, hanya dibatasi oleh partisi-partisi kayu yang berukuran $100 \mathrm{~cm}$. Akan tetapi, terdapat rolling door pada lantai 1 sehingga apabila bangunan sedang tidak beroperasi para pengunjung 
tidak dapat keluar masuk ke dalam ruangan dan bangunan tetap aman. Area luar yang ada pada lantai 1 depan bangunan merupakan area mural yang memiliki karakter third place yaitu playful, conversation, dan neutral karena terdapat bangku-bangku dan penghijauan yang dapat membuat para pengujung merasa nyaman dalam berinteraksi dan bersantai.

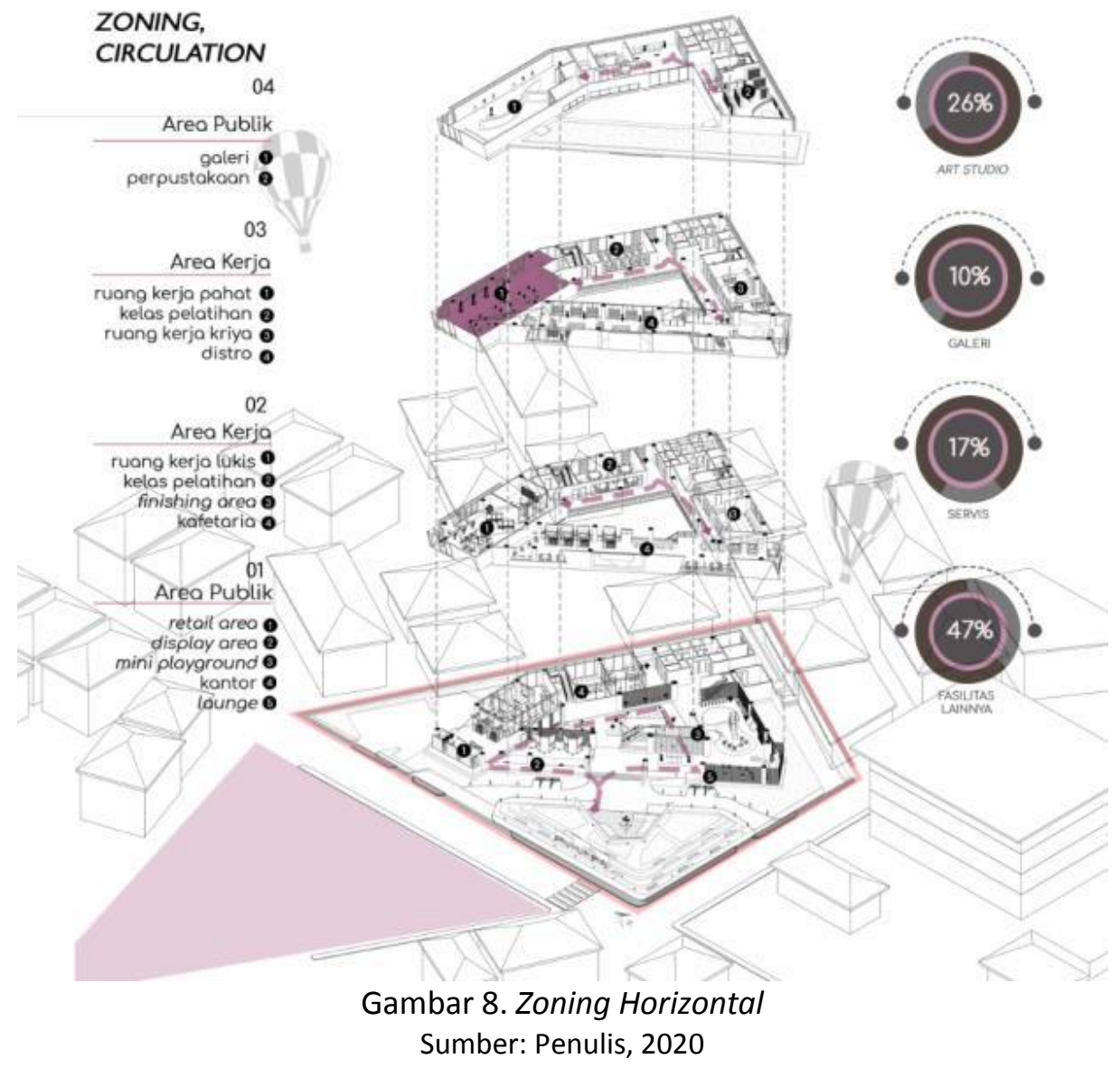

Lantai 2 dan lantai 3 merupakan area kerja seni yang bersifat reguler. Pada lantai 2, terdapat ruang kelas pelatihan anak-anak, ruang kerja seni lukis, finishing area (pemasangan, penyemprotan, dan pengeringan), dan area kios makan. Pada lantai 3, terdapat ruang kelas pelatihan dewasa, ruang kerja seni patung/pahat, ruang kerja seni kriya/mozaik, dan distro/artshop tempat dimana para pengunjung dapat membeli atau menjual karya mereka. Sedangkan, pada lantai 4 terdapat fasilitas umum yaitu galeri dan perpustakaan yang bersifat netral dan terbuka bagi siapa saja. Proyek ini memiliki tempat parkir yang terdiri dari 7 buah kendaraan mobil dan 10 buah kendaraan motor yang terletak di bagian utara bangunan. Parkiran yang disediakan tidak begitu banyak karena target pengujung adalah masyarakat yang ada di kawasan Kelurahan Meruya Utara. Disediakan juga parkir sepeda pada bagian depan bangunan untuk mempermudah akses ke dalam bangunan.

\section{Fasad dan Strategi Desain}

Fasad bangunan pada tampak depan menggunakan bata dimana bata tersebut dihiasi dengan lukisan mural sehingga bangunan terlihat menarik dan mencerminkan program yang ada pada bangunan, yaitu program seni rupa terutama di bidang lukis. Fasad bata divariasikan dengan kaca agar bangunan tidak terkesan padat atau monoton dan tercukupinya pencahayaan dan pengudaraan pada bangunan. Pada tampak depan, terdapat billboard tv yang berfungsi untuk menampilkan karya-karya seni terbaik yang dibuat oleh para pengunjung. 


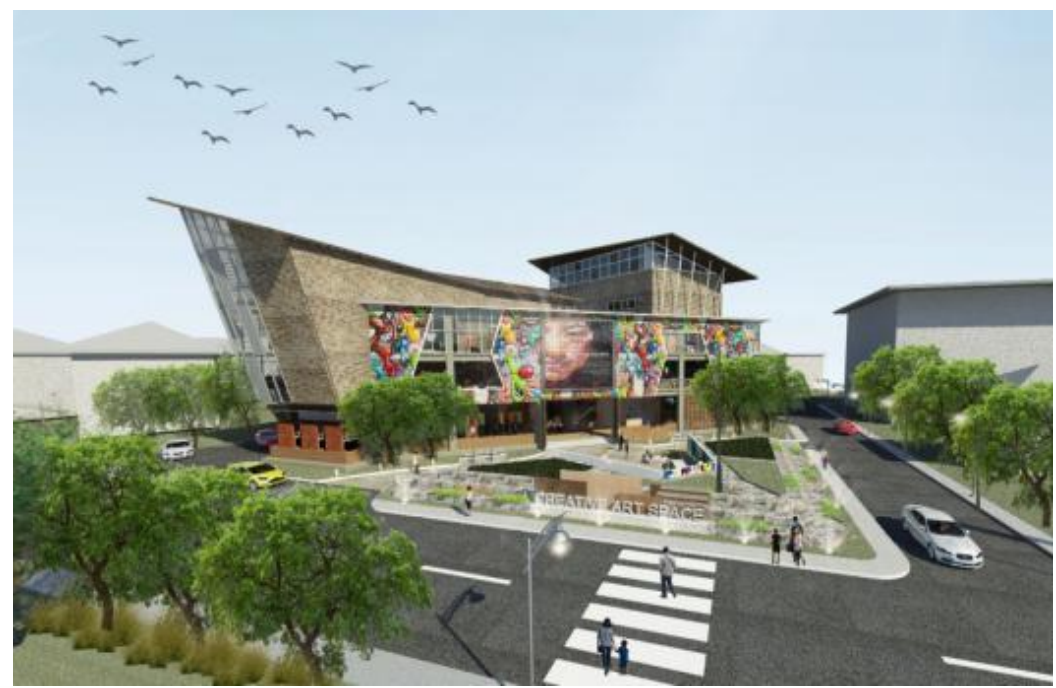

Gambar 9. Perspektif Eksterior

Sumber: Penulis, 2020

Desain ruang yang ada di dalam bangunan disesuaikan dengan program yang ada. Pada bangunan, terdapat 3 ruang kerja yaitu ruang kerja lukis, ruang kerja patung/pahat, dan ruang kerja kriya/mozaik. Ruang kerja umumya memiliki luas yang lebih besar dibandingkan dengan fungsi lainnya. Ruang kerja dilengkapi dengan area cuci dan penyimpanan. Lantai yang digunakan pada area kerja adalah keramik dengan motif kayu sehingga ruangan tetap terasa sejuk dan mudah dibersihkan. Area ruang kerja memiliki salah satu kriteria dari third place yaitu reguler dimana pengunjung mempunyai kebutuhan untuk datang ketempat ini seperti melatih dan mengasah kemampuan mereka dalam berkreativitas di bidang seni rupa. Selain itu, pengunjung juga dapat berekspresi dengan bebas di dalam ruang kerja seni tersebut. Setiap ruang kerja memiliki desain yang berbeda-beda dimana pada ruang kerja lukis penempatan kursi dan tempat lukis disusun mengitari objek yang akan dilukis. Pada ruang kerja patung/pahat, meja disusun dibagian tengah ruang berhadap-hadapan agar interaksi antar pengajar dan pelajar dapat terjalin dengan mudah. Sedangkan pada ruang kerja kriya/mozaik meja dan kursi disusun seperti ruang-ruang kelas pada umumnya.
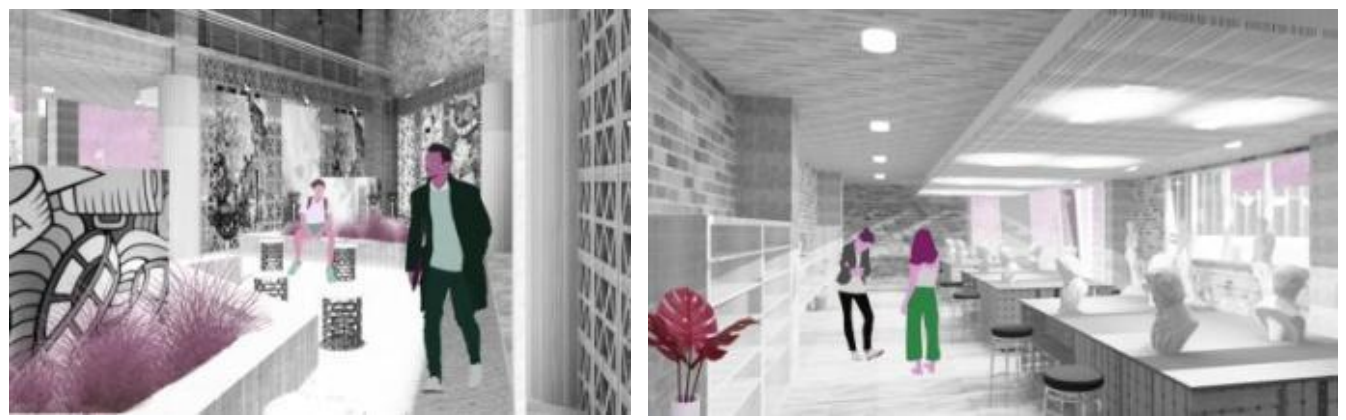

Gambar 10. Perspektif Display Area Outdoor dan Ruang Kerja Patung/Pahat

Sumber: Penulis, 2020

Ruang publik yang ada pada bangunan seperti mural, galeri, dan display area merupakan ruang yang bersifat neutral dan playful dimana para pengunjung dapat melakukan interaksi sosial sekaligus menikmati hasil karya seni yang ada. Ruang ini tentunya memenuhi salah satu kriteria dari third place. Ruang mural dan ruang display merupakan area outdoor, sedangkan ruang galeri apabila tidak ada event tertentu dapat digunakan sebagai ruang serbaguna. Pada galeri, hasil karya lukisan dipajang dengan cara digantung dengan menggunakan kabel agar dapat diatur ketinggiannya sesuai dengan jarak pandang para pengunjung. 


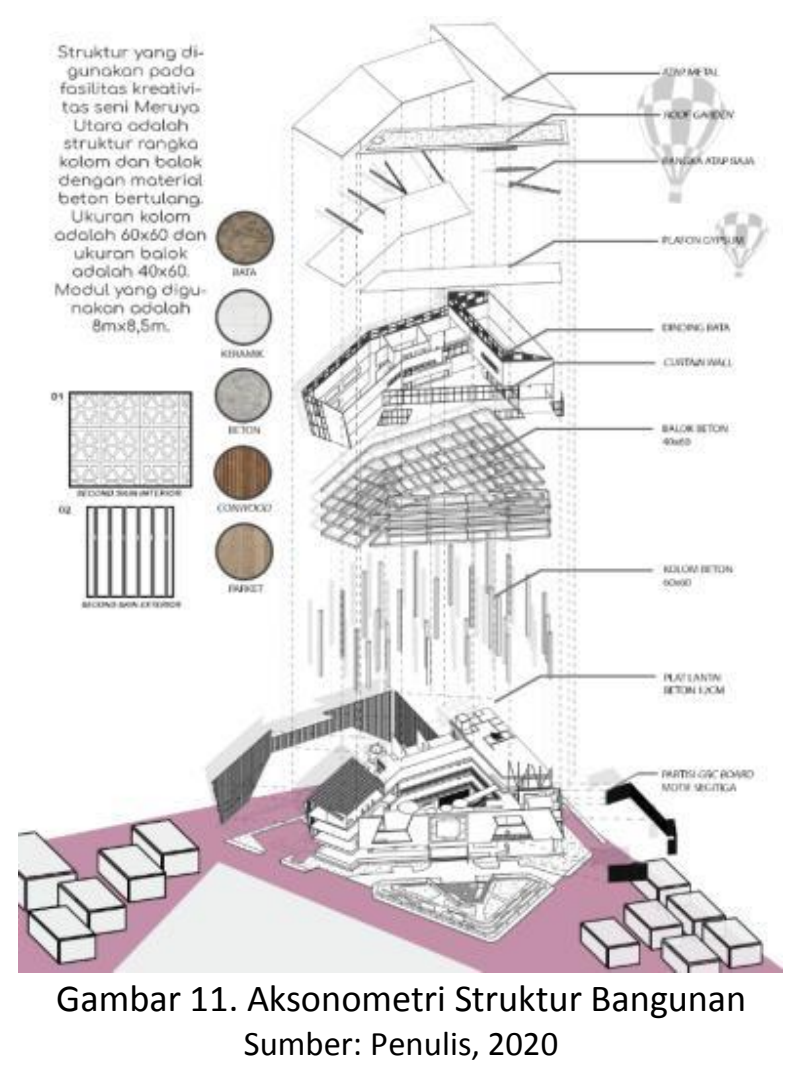

Struktur yang digunakan pada fasilitas kreativitas seni Meruya Utara adalah struktur rangka kolom dan balok dengan material beton bertulang. Ukuran kolom adalah $60 \times 60 \mathrm{~cm}$ dan ukuran balok adalah $40 \times 60 \mathrm{~cm}$. Modul yang digunakan adalah $8 \times 8,5 \mathrm{~m}$. Pada lantai, struktur yang digunakan adalah plat lantai beton. Sedangkan, struktur atap ada 2, yaitu menggunakan struktur rangka baja pipa dengan penutup atap bermaterialkan metal dan atap beton yang digunakan sebagai roof garden pada bangunan. Dinding bangunan bermaterialkan bata alami yang di expose dengan tebal $15 \mathrm{~cm}$ yang divariasikan dengan kaca. Fasad bangunan bagian timur dan utara dilapisi dengan second skin bergaris yang bermaterialkan conwood. Sedangkan, material partisi pada interior bangunan adalah GRC motif kayu dengan desain segitiga. Kayu dapat memberikan kesan natural pada bangunan dan teksturnya yang beragam dapat membuat visual bangunan menjadi lebih menarik dan membuat para pengunjung merasa nyaman.

Bukaan pada dinding merupakan jendela hidup, memungkinkan pengudaraan alami dan sinar matahari dapat masuk kedalam ruangan. Sedangkan, lantai bermaterialkan keramik pada ruang kerja dan lantai parket kayu pada perpustakaan, galeri, kafetaria maupun distro/artshop. Untuk area outdoor mural, lantai menggunakan batu paving dan dinding untuk melukis mural bermaterialkan bata yang di cat putih.

\section{KESIMPULAN DAN SARAN}

Fasilitas kreativitas seni Meruya Utara mampu meningkatkan kualitas kreativitas warga dalam mengisi waktu luangnya secara positif karena terdapat berbagai macam program yang menarik, yaitu program seni rupa dibidang lukis, patung/pahat, kriya/mozaik, dan mural/grafiti. Program-program yang ada tentunya dapat mengasah kemampuan warga dalam berkreativitas sehingga warga dapat mengembangkan dirinya menjadi pribadi yang lebih baik, membantu dalam menyelesaikan masalah dengan mudah, dan menjadikan kehidupan seseorang lebih berhasil. Fasilitas ini juga menjawab kebutuhan warga Meruya Utara dalam 
berekspresi dan bersosialisasi secara positif karena program yang disediakan terbuka bagi siapa saja tidak dibatasi oleh kalangan tertentu dan terdapat program yang bersifat reguler sehingga warga dapat merasa nyaman dalam mengekspresikan dirinya secara bebas. Fasilitas juga dilengkapi dengan program pendukung seperti taman, kafetaria, dan distro yang memungkinkan para pengunjung untuk berkumpul, berbincang-bincang, dan mengutarakan pendapat secara terbuka. Fasilitas ini diharapkan dapat menghasilkan generasi yang lebih baik sekaligus memajukan kawasan Meruya Utara.

\section{REFERENSI}

Badan Pusat Statistik. (2019). Kecamatan Kembangan Dalam Angka 2019. Jakarta: Badan Pusat Statistik Kota Administrasi Jakarta Barat

Borrup, T. (2010). Shaping a Creative Milieu : Creativity, Process, Pedagogy, Leadership and Place dalam Journal of Urban Culture Research. Vol. 1. 2010. Faculty of Fine and Applied Art Chulalongkorn University

Evans, G. Jo Foord. Meric S Gertler. Lori Tesolin. Sarah Weinstock. (2006). Strategies for Creative Spaces and Cities: Lessons Learned. Research Team: Cities Institute, London Metropolitan University.

Oldenburg, R. (1999). The Great Good Place: Cafes, Coffe Shops, Bookstores, Bars, Hair Salons, and Other Hangouts at the Heart of a Community. USA: Marlowe \& Company.

Suryahadi, A. (2008). Seni Rupa Jilid 1. Jakarta: Direktorat Jenderal Manajemen Pendidikan Dasar dan Menengah

Treffinger, D.J. (1980). A Preliminary Models of creative Learning. Gifted child Quarterly, 24f, 127-138.

Tchumi, B. (1996). Architecture and Disjuction. MIT Press.

Arifin. S. (2010). Seni dan Kreativitas. Diunduh 13 Februari 2020, melalui https://www.kompasiana.com/saseful_arifin/550039108133112019fa7266/seni-dankreativitas.

Buana, S. (2015). Ruang Kreatif Publik. Diunduh 13 Februari 2020, melalui https://www.kompasiana.com/madebhela/560ac4b02d7a61d319ab52db/ruang-kreatifpublikmewujudkan-lingkungan-kreatif-untuk-warga-kota?page=all.

Cartwright, L. (2017). What Are Creative Art Spaces and Why Do They Exist. Diunduh 14 Februari 2020, melalui http://tandfonline.com/ doi/full/10.1080/02604027.2017. 